\title{
PENGARUH APLIKASI COMPOST TEA YANG MENGANDUNG B.bassiana TERHADAP KEANEKARAGAMAN ARTHROPODA, PERTUMBUHAN, DAN PRODUKSI TANAMAN PADI
}

\section{THE EFFECT OF COMPOST TEA APPLICATIONS CONTAINING B.bassiana ON ARTHROPODA, GROWTH, AND PRODUCTION OF RICE PLANT}

\author{
Umi Sholikhatin ${ }^{1}$, Purnomo ${ }^{2}$, Agus M. Hariri² ${ }^{2}$ Yuyun Fitriana ${ }^{2}$ \\ ${ }^{1}$ Jurusan Agroteknologi, Fakultas Pertanian, Universitas Lampung, Bandar Lampung, Indonesia \\ ${ }^{2}$ Jurusan Proteksi Tanaman Fakultas Pertanian, Universitas Lampung, Bandar Lampung, Indonesia \\ *Email: usholikhatin@gmail.com \\ *Corresponding Author, Diterima: 25 Feb. 2021, Direvisi: 2 Mar. 2021, Disetujui: 20 Apr.. 2021
}

\begin{abstract}
The aim of this research was to understand the effect of Beauveria bassiana contained in compost tea on arthropod diversity in rice plants and the effect of compost tea containing B. bassiana to increase the growth and production of rice plants. The research was conducted in Sumber Sari Hamlet, HajimenaVillage, Natar Sub district, South Lampung and laboratory analysis was conducted in Greenhouse and Plant Protection Laboratory, Faculty of Agriculture the University of Lampung from May to September 2016. The treatments were arranged in a Randomized Block Design (RBD) consisting of 5 treatments, each treatment combination was repeated 4 times. This research carried out on paddy fields consisting of 3 plots. The variance of data obtained were analyzed and differences in mean values of the treatments were tested using the Least Significant Difference test (LSD) at the 5\% level. The results show compost tea and B. bassiana on rice plants have a significant effect on increasing plant height, leaf greenness, and weights, while the amount arthropods are not significantly different. The most commonly found order of arthropods is the Diptera order, Phoridae and Drosophilidae families. In cucumber plants, it appears that the treatment significantly affect all observed variables except the root length observation variables.
\end{abstract}

Keywords: Arthropods, Beauveria bassiana, compost tea, cucumber, rice.

\begin{abstract}
ABSTRAK
Penelitian ini bertujuan untuk mempelajari pengaruh Beauveria bassiana yang terkandung dalam compost tea terhadap keanekaragaman arthropoda pada tanaman padi dan pengaruh compost tea yang mengandung Beauveria bassiana untuk meningkatkan pertumbuhan dan produksi tanaman padi. Penelitian ini dilakukan di Dusun Sumber Sari Desa Hajimena Kecamatan Natar, Lampung Selatan, dan analisis laboratorium dilakukan di Rumah Kaca dan Laboratorium Proteksi Tanaman Fakultas Pertanian Universitas Lampung dari bulan MeiSeptember 2016. Perlakuan disusun dalam Rancangan Acak Kelompok (RAK) terdiri dari 5 perlakuan, setiap kombinasi perlakuan diulang 4 kali. Penelitian ini dilakukan pada lahan sawah yang terdiri dari 3 plot. Data dianalisis dengan sidik ragam dan perbedaan nilai tengah perlakuan diuji Beda Nyata Terkecil (BNT) pada taraf 5\%. Hasil penelitian menunjukkan compost tea dan Beauveria bassiana pada tanaman padi berpengaruh nyata meningkatkan tinggi tanaman, kehijauan daun dan bobot berangkasan, sedangkan jumlah arthropoda tidak
\end{abstract}


berbeda nyata. Jenis arthropoda yang paling banyak ditemukan adalah ordo Diptera, family Phoridae dan Drosophilidae. Pada tanaman timun tampak bahwa perlakuan berpengaruh nyata meningkatkan semua variabel pengamatan kecuali pada variabel pengamatan panjang akar.

Kata kunci : Arthropoda, Beauveria bassiana, compost tea, mentimun, padi.

\section{PENDAHULUAN}

Jumlah penduduk di Indonesia selalu mengalami peningkatan dari tahun ke tahun, hal ini menyebabkan semakin meningkatnya kebutuhan akan beras (Swastika et al., 2007). Menurut BPS (2017), produksi beras Indonesia pada tahun 2017 yaitu 81,38 juta ton, produksi ini sudah meningkat, namun Indonesia masih melakukan impor beras mencapai 256,56 ribu ton dan pada 2018 terjadi peningkatan jumlah impor yaitu mencapai 1,12 juta ton (BPS, 2018). Menurut Agus et al. (2004), pemakaian pupuk anorganik yang berlebihan akan menambah tingkat polusi tanah yang akhirnya berpengaruh juga terhadap kesehatan manusia. Untuk itu perlu dicari alternatifmengatasi permasalahan tersebut, diantaranya dengan pupuk organik cair.

Salah satu jenis pupuk organik cair adalah watery fermented compost extract atau yang lebih dikenal dengan compost tea. Compost tea merupakan ekstrak kompos yang diproduksi dengan mencampur kompos dengan air dan dibiarkan selama 2-8 hari dengan penambahan molasses atau gula di dalam kompos selama proses produksi. Kandungan anti mikroba dalam compost tea dapat dimanfaatkan sebagai biobakterisida (Hmouni et al., 2006).

Selain kesuburan tanah, permasalahan hama dan penyakit tanaman juga menjadi faktor pembatas peningkatan produksi padi. Menurut Baehaki (2013), kehilangan hasil padi akibat serangan penggerek batang yaitu 31,68 kg GKP/ha. Untuk mengatasi permasalahan tersebut perlu alternatif pengendalian yang lebih baik, aman dan ramah lingkungan. Salah satunya menggunakan jamur entomopatogen yaitu B. bassiana. Jamur ini efektif untuk membunuh serangga ordo Coleoptera, Lepidoptera, Thysanoptera, Hemipter, Homoptera, Orthoptera dan Diptera (Herlinda et al., 2008). Oleh karena itu, dilakukan penelitian untuk mengetahui pengaruh pupuk kompos cair (compost tea) yang sekaligus mengandung agensi hayati (jamur B. bassiana) dalam mengendalikan hama dan meningkatkan produksi tanaman padi. Penelitian ini bertujuan untuk mempelajari pengaruh $B$. bassiana yang terkandung dalam compost tea terhadap keanekaragaman arthropoda pada tanaman padi serta mempelajari pengaruh compost tea yang mengandung B. bassiana untuk meningkatkan pertumbuhan dan produksi tanaman padi.

\section{BAHAN DAN METODE}

Penelitian ini dilakukan di Dusun Sumber Sari Desa Hajimena Kecamatan Natar, Lampung Selatan, dan analisis laboratorium dilakukan di Rumah Kaca dan Laboratorium Proteksi Tanaman Fakultas Pertanian Universitas Lampung dari bulan Mei-September 2016.

Bahan yang digunakan adalah benih padi varietas Ciherang, benih mentimun, beras, biakan jamur B. bassiana., agar, kentang, aquades, gula pasir, 
kompos kering, compost tea, pupuk urea, SP-36 dan mutiara serta herbisida pra tumbuh. Sedangkan Alat yang digunakan dalam penelitian adalah cawan petri, beaker glass, tabung reaksi, timbangan digital, oven, plastik wrap, almunium foil, plastik tahan panas, erlenmeyer, nampan, jarum ose, bor gabus, batang L, bunsen, autoklaf, laminar air flow, ember plastik (ukuran 25L), ayakan, aquarium pump, saringan, sweep nets, hand sprayer semi otomatis, meteran, tali rafia, patok, poli bag, gunting, meteran dan mistar.

Penelitian ini menggunakan Rancangan Acak Kelompok (RAK) yang terdiri dari 5 perlakuan, yaitu terdiri dari perlakuan jamur B. bassiana dan compost tea $(\mathrm{P} 1)$, compost tea murni (P2), aplikasi B. bassiana murni (P3), tanpa aplikasi (P4) serta perlakuan yang sesuai dengan petani (P5). Setiap kombinasi perlakuan diulang sebanyak 4 kali sehingga terdapat 20 satuan percobaan. Penelitian ini dilaksanakan pada sawah. Lahan sawah terdiri dari 3 plot dengan ukuran $5 \mathrm{~m}$ x $5 \mathrm{~m}$.

\section{Perbanyakan Beauveria bassiana}

Biakan murni jamur B. bassiana ditumbuhkan ke dalam media PDA dan diinkubasi selama 6-8 hari. Kemudian jamur B. bassiana diperbanyakan pada media beras, kemudian diinokulasikan biakan Beauveria bassiana yang telah tumbuh pada media PDA sebanyak \pm 7 bor gabus dan diinkubasi hingga jamur tumbuh merata.

\section{Penyediaan Compost Tea}

Kompos kering diayak terlebih dahulu, setelah itu diambil sebanyak 3600 gr, gula pasir 400 gr dan air sebanyak 20 L yang dimasukkan ke dalam ember plastik (ukuran $25 \mathrm{~L}$ ) dan dipasang aquarium pump (pastikan selang output mencapai dasar ember).
Kompos didiamkan selama 4 hari setelah itu compos tea siap digunakan.

\section{Penyiapan larutan compost tea plus B. bassiana} dan larutan B. bassiana

Compost tea yang telah jadi disaring (dipisahan antara air dan ampasnya), kemudian dimasukkan kedalam ember sebanyak 81 dan ditambahkan jamur B. bassiana sebanyak $100 \mathrm{~g}$ dengan saringan $0,1 \mathrm{ml}$. Setelah itu larutan tersebut di masukkan kedalam hand sprayer semi otomatis dan siap digunakan. Cara yang sama dilakukan utuk membuat larutan B. bassiana, namun larutan compost diganti dengan aquades sebanyak 81. Larutan compost tea dan larutan jamur B. bassiana tersebut kemudian dibagi menjadi 4, sehingga didapatkan 21 larutan untuk masing-masing perlakuan.

\section{Penyiapan Plot Pertanaman Padi \\ Persiapan Padi dan Persemaian}

Benih yang digunakan adalah varietas Ciherang. Benih direndam selama 24 jam. Lahan persemaian diolah secara intensif. Pengairan dilakukan setelah bibit membentuk daun.

\section{Penanaman}

Penanaman dilakukan dengan cara pindah tanam dengan menggunakan bibit umur 21 hari setelah semai. Penanaman dilakukan pada lahan sawah teknis yang diolah secara intensif. Penanaman dengan jarak tanam $25 \times 25 \mathrm{~cm}$ dengan 3 bibit perlubang tanam. Lahan sawah terdiri dari 3 plot dengan ukuran $5 \mathrm{~m} \times 5 \mathrm{~m}$.

\section{Pemupukan}

Pemupukan dilakukan dua kali yaitu umur 1 minggu setelah tanam (mst) dan 5 mst. Pemupukan pertama $1 / 2$ dosis urea dan seluruh dosis SP-36 dan KCL, dan pemupukan keduasisa dosis. Dosis pupuk 
yang digunakan adalah urea $350 \mathrm{~kg} / \mathrm{ha}$, SP-36 200 kg/ha dan KCL 200 kg/ha. Pemupukan dilakukan dengan sistem tebar.

\section{Perlakuan Petani}

Perlakuan yang dilakukan oleh petani menggunakan pupuk sintetik dan pestisida non hayati. Pemupukan susulan pertama dilakkan pada padi berumur 7 sampai 10 HST (Hari Setelah Tanam). Pupuk yang digunakan adalah Urea $75 \mathrm{~kg} / \mathrm{ha}$ SP-36 100 kg/ha dan KCL 50 kg/ha. Pemupukan susulan kedua diberikan pada saat padi berumur 21 HST menggunakan pupuk Urea sebanyak $150 \mathrm{~kg} / \mathrm{ha}$ dan yang ketiga pada saat umur padi 42 HST menggunakan Urea $75 \mathrm{~kg} /$ ha dan KCL $50 \mathrm{~kg} / \mathrm{ha}$. Sedangkan pestisida yang digunakan untuk Bentan dengan bahan aktifFentin Asetat 45\% untuk mengendalikan keong emas.

\section{Pembuatan Suspensi Jamur Beauveria bassiana}

Spora jamur B. bassiana pada media beras dipanen dengan menggunakan air steril sebanyak $2 \mathrm{~L}$ dan dibuat suspense dengan kerapatan $10^{8} \mathrm{spora} / \mathrm{ml}$. Suspensi tersebut yang akan digunakan sebagaiperlakuan di lapangan.

\section{Aplikasi Compost Tea dan Beauveria bassiana dipertanaman Padi}

Aplikasi menggunakan hand sprayer semi otomatis sebanyak 2 L larutan per perlakuan. Aplikasi ini di lakuan secara berkala sebanyak 4 (empat) kali yaitu pada umur 21, 35, 45, 60 hari setelah tanam (hst) sesuai dengan perlakuan.

\section{Pengamatan Kemelimpahan Arthropoda Hama dan Musuh Alami pada Tanaman Padi}

Pengamatan dilakukan dengan menghitung jenis dan jumlah serangga hama dan musuh alami yang terdapat di setiap rumpun yang diamati pada setiap perlakuan. Pengamatan dilakukan dengan menggunakan metode Sweep nets (Jala ayun) yang dilakukan seminggu sekali.

\section{Pengamatan Infeksi Beauveria bassiana terhadap pada Tanaman Padi}

Infeksi B. bassiana diamati dengan cara menghitung jenis dan jumlah serangga target dan non target yang terinfeksi di setiap rumpun pengamatan pada setiap perlakuan.

\section{Pertumbuhan dan Hasil Tanaman Padi}

Parameteryang diamati yaitu tinggi tanaman per 2 minggu, jumlah anakan tiap rumpun dan potensi hasil produksi. Satu unit percobaan merupakan petak pertanaman padi berukuran $5 \mathrm{~m}$ x $5 \mathrm{~m}$. Satu petak diambil 6 rumpun tanaman padi yang diambil secara acak dengan arah diagonal untuk diamati.

\section{Metode Penilitian pada Tanaman Mentimun}

Pada penelitian tambahan ini percobaan disusun menggunakan Rancangan Acak Kelompok (RAK) yang terdiri dari 9 perlakuan, yaitu terdiri dari perlakuan Kontrol Siram (Ksr), Kontrol Semprot (Ksm), Kontrol Semprot Siram (Kss), Siram compost tea (Sr), Semprot compost tea $(\mathrm{Sm})$, Siram Semprot compost tea $(\mathrm{Ss})$, Siram compost tea + B. bassiana (Srbb), Semprot compost tea + B. bassiana $(\mathrm{Smbb})$ dan Siram Semprot compost tea + B. bassiana (Ssbb). Perlakuan tersebut terdiri dari kontrol hanya dengan air, siram dan semprot dengan menggunakan compost tea saja dan untuk Siram dan Semprot B. bassiana menggunakan compost tea + B. bassiana. Setiap kombinasi perlakuan diulang sebanyak 5 kali sehingga terdapat 45 satuan percobaan. Penelitian ini menggunakan rumah 
kaca yang terdiri dari 2 plot, diplot pertama terdapat 23 polibag dan diplot kedua terdapat 22 polibag.

\section{Analisis Data}

Data yang dikumpulkan dalam penelitian ini adalah 1.) Kelimpahan arthropoda hama dan musuh alami, infeksi B. bassiana. terhadap serangga target dan non target serta 2.) Pertumbuhan dan hasiltanaman padi. Data yang didapatkan kemudian diolah menggunakan sidik ragam dan dilanjutkan denganuji Beda Nyata Terkecil (BNT) dengan taraf nyata 5\%.

\section{HASIL DAN PEMBAHASAN}

Hasil penelitian membahas lima bagian yakni tinggi tanaman, jumlah anakan, kehijauan daun, jumlah arthopoda dan hasil panen ( bobot berangkasan, bobot 100 butir dan kadar air benih) untuk setiap perlakuan. Hasil penelitian tersebut dijelaskan sebagai berikut.

\section{Hasil Pengamatan Tinggi Tanaman Padi 5 Minggu} Setelah Tanam

Hasil penelitian menunjukkan bahwa tinggi tanaman padi tidak berbeda nyata pada perlakuan Compost tea yang mengandung B. bassiana dibandingkan dengan perlakuan lain hingga 5 minggu setelah tanam (MST). Hal tersebut dapat dilihat pada Tabel 1.

Jumlah Anakan Tanaman Padi 5 Minggu Setelah Tanam

Hasil penelitian menunjukkan bahwa jumlah anakan tanaman padi tidak berbeda nyata pada perlakuan Compost tea yang mengandung $B$. bassiana dibandingkkan dengan perlakuan lain hingga 5 MST. Hal tersebut dapat dilihat pada Tabel 2.

\section{Kehijauan Daun Tanaman Padi}

Hasil penelitian menunjukkan bahwa pada perlakuan compost tea dancompost tea $+B$.

Tabel 1. Pengaruh Aplikasi Compost Tea yang Mengandung B. bassiana terhadap Tinggi Tanaman Padi

\begin{tabular}{lccccc}
\hline \multirow{2}{*}{ Perlakuan } & \multicolumn{5}{c}{ Pengamatan $\mathrm{ke}-(\mathrm{MST})(\mathrm{cm})$} \\
\cline { 2 - 6 } & 1 & 2 & 3 & 4 & 5 \\
\hline Kontrol & $40,51 \mathrm{~b}$ & $50,23 \mathrm{~b}$ & $71,87 \mathrm{~b}$ & $110,10 \mathrm{a}$ & $114,85 \mathrm{~b}$ \\
Perlakuan Petani & $40,80 \mathrm{~b}$ & $50,94 \mathrm{~b}$ & $75,10 \mathrm{~b}$ & $109,31 \mathrm{a}$ & $116,52 \mathrm{ab}$ \\
BB & $43,20 \mathrm{a}$ & $52,94 \mathrm{a}$ & $77,77 \mathrm{a}$ & $112,38 \mathrm{a}$ & $117,10 \mathrm{a}$ \\
Compost & $42,09 \mathrm{ab}$ & $52,58 \mathrm{a}$ & $76,96 \mathrm{a}$ & $114,10 \mathrm{a}$ & $119,63 \mathrm{a}$ \\
Compost + BB & $43,17 \mathrm{a}$ & $53,03 \mathrm{a}$ & $80,27 \mathrm{a}$ & $112,81 \mathrm{a}$ & $120,38 \mathrm{a}$ \\
\hline
\end{tabular}

Keterangan : Angka-angka yang diikuti oleh huruf yang sama pada kolom yang sama menunjukkan tidak berbeda nyata pada Uji Beda Nyata Terkecil (BNT) 5\%.

Tabel 2. Pengaruh Aplikasi Compost Tea yang Mengandung Beauveria bassiana (Bals.)Vuill. terhadapJumlah Anakan Tanaman Padi

\begin{tabular}{lccccc}
\hline \multirow{2}{*}{ Perlakuan } & \multicolumn{5}{c}{ Pengamatan ke - (MST) (Batang) } \\
\cline { 2 - 6 } & 1 & 2 & 3 & 4 & 5 \\
\hline Kontrol & $13,79 \mathrm{a}$ & $16,42 \mathrm{a}$ & $19,17 \mathrm{a}$ & $24,29 \mathrm{a}$ & $23,75 \mathrm{a}$ \\
Perlakuan Petani & $12,04 \mathrm{a}$ & $14,92 \mathrm{a}$ & $17,83 \mathrm{a}$ & $22,13 \mathrm{a}$ & $22,50 \mathrm{a}$ \\
BB & $13,71 \mathrm{a}$ & $16,38 \mathrm{a}$ & $19,25 \mathrm{a}$ & $24,46 \mathrm{a}$ & $23,92 \mathrm{a}$ \\
Compost & $14,67 \mathrm{a}$ & $17,25 \mathrm{a}$ & $20,08 \mathrm{a}$ & $25,25 \mathrm{a}$ & $25,50 \mathrm{a}$ \\
Compost + BB & $14,29 \mathrm{a}$ & $16,75 \mathrm{a}$ & $19,67 \mathrm{a}$ & $24,83 \mathrm{a}$ & $25,08 \mathrm{a}$ \\
\hline
\end{tabular}

Keterangan : Angka-angka yang diikuti oleh huruf yang sama pada kolom yang sama menunjukkan tidak berbeda nyata pada Uji Beda Nyata Terkecil (BNT) 5\%. 
bassiana berbeda nyata dengan perlakuan lain. Perlakuan tersebut memiliki tingkat kehijauandaun tertinggi yaitu sebesar 21,11 ccidan 21,60 cci (chlorophyl content index). Hal tersebut dapat dilihat pada Tabel 3.

\section{Jumlah Arthropoda Tanaman Padi 7 Minggu}

\section{Setelah Aplikasi}

Hasil penelitian menunjukkan bahwa jumlah arthropoda tanaman padi tidak berbeda nyata pada perlakuan Compost tea yang mengandung B. bassiana dibandingkkan dengan perlakuan lain hingga 5 minggu setelah tanam (MST). Hal tersebut dapat dilihat pada Tabel 4.

\section{Keanekaragaman dan populasi ordo serangga di}

\section{lahan Penelitian Tanaman Padi}

Hasil identifikasi ordo-ordo serangga pada tanaman padi dalam penelitian ini ditemukan sebanyak 8 ordo serangga. Ordo-ordo tersebutadalah Orthoptera,

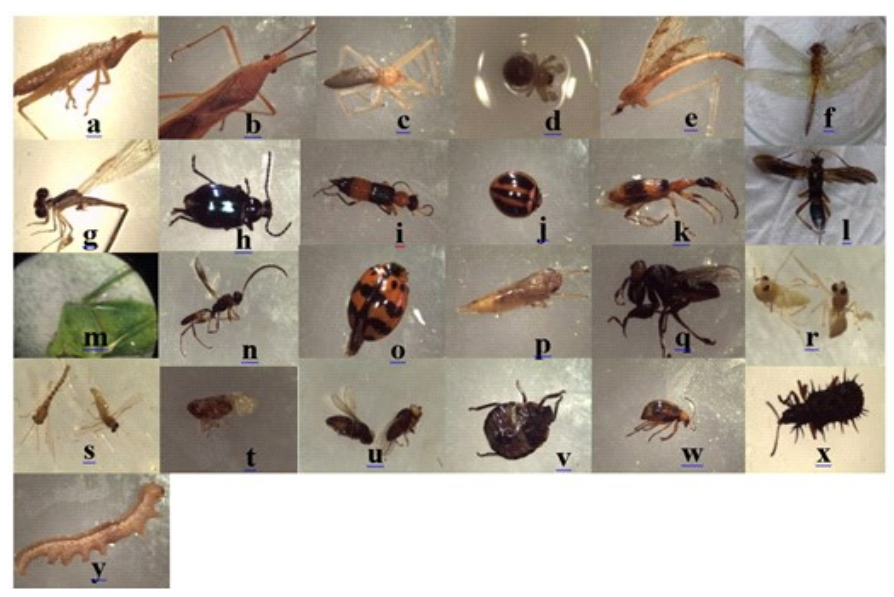

Gambar 1. Ordo Orthoptera family acrididae (a); ordo Hemiptera family Alydidae (b); ordo araneida family Tetragnathidae (c); ordo araneida family Thomisidae (d); ordo Diptera familyAsilidae; (f) ordo Odonata family libellulidae; (g) ordo Odonata family Coenagrionidae (e); ordo Coleoptera family Chrysomelidea (h); ordo Coleoptera family Staphylinidae (i); ordo Coleoptera family Coccinellidae (j); ordo Coleoptera family Carabidae (k); ordo Hymenoptera(l); ordo Hemiptera family Pentatomidae (m); ordo Hymenoptera (n); ordo Coleoptera family Coccinellidae (o); ordo Hemiptera family Cicadellidae (p); ordo Diptera (q); ordo Diptera family Phoridae (r); ordo Diptera family Chironomidae (s); ordo Hemiptera family Delpacidae (t); ordo Hemiptera family Pentatomidae (u); ordo Diptera family Drosophilidae (v); ordo Coleoptera family galerucidae (w); ordo Coleoptera family Hispidae (x); dan ordo Lepidoptera family giometridae (y) (Borror, 1992).

Tabel 3. Pengaruh Aplikasi Compost Tea yang Mengandung Beauveria bassiana (Bals.)Vuill. terhadap Pengamatan Kehijauan Daun pada Tanaman Padi

\begin{tabular}{lc}
\hline \multicolumn{1}{c}{ Perlakuan } & Kehijauan Daun (cii) \\
\hline Kontrol & $16,17 \mathrm{~b}$ \\
Perlakuan Petani & $16,28 \mathrm{~b}$ \\
BB & $19,47 \mathrm{~b}$ \\
Compost & $21,11 \mathrm{a}$ \\
Compost + BB & $21,60 \mathrm{a}$ \\
\hline
\end{tabular}

Keterangan : Angka-angka yang diikuti oleh huruf yang sama pada kolom yang sama menunjukkan tidak berbeda nyata pada Uji Beda Nyata Terkecil (BNT) 5\%. 
Tabel 4. Pengaruh Aplikasi Compost Tea yang Mengandung Beauveria bassiana (Bals.) Vuill. terhadapJumlah Arthropoda pada Tanaman Padi

\begin{tabular}{lcccccccc}
\hline \multirow{2}{*}{ Perlakuan } & \multicolumn{7}{c}{ Pengamatan ke-(MSA) (ekor) } \\
\cline { 2 - 9 } & 0 & 1 & 2 & 3 & 4 & 5 & 6 & 7 \\
\hline Kontrol & $42,25 \mathrm{a}$ & $34,50 \mathrm{a}$ & $38,75 \mathrm{a}$ & $74,50 \mathrm{a}$ & $93,25 \mathrm{a}$ & $94,00 \mathrm{a}$ & $93,75 \mathrm{a}$ & $92,25 \mathrm{a}$ \\
Perlakuan Petani & $33,50 \mathrm{a}$ & $35,50 \mathrm{a}$ & $46,25 \mathrm{a}$ & $73,25 \mathrm{a}$ & $85,50 \mathrm{a}$ & $91,00 \mathrm{a}$ & $94,00 \mathrm{a}$ & $93,50 \mathrm{a}$ \\
BB & $48,75 \mathrm{a}$ & $31,50 \mathrm{a}$ & $22,50 \mathrm{a}$ & $58,75 \mathrm{a}$ & $68,25 \mathrm{a}$ & $67,00 \mathrm{a}$ & $68,7 \mathrm{a}$ & $70,75 \mathrm{a}$ \\
Compost & $30,00 \mathrm{a}$ & $35,75 \mathrm{a}$ & $33,75 \mathrm{a}$ & $64,50 \mathrm{a}$ & $84,75 \mathrm{a}$ & $87,00 \mathrm{a}$ & $88,50 \mathrm{a}$ & $90,25 \mathrm{a}$ \\
Compost + BB & $20,25 \mathrm{a}$ & $26,00 \mathrm{a}$ & $26,00 \mathrm{a}$ & $75,75 \mathrm{a}$ & $83,75 \mathrm{a}$ & $76,25 \mathrm{a}$ & $78,25 \mathrm{a}$ & $77,75 \mathrm{a}$ \\
\hline
\end{tabular}

Keterangan : Angka-angka yang diikuti oleh huruf yang sama pada kolom yang sama menunjukkan tidak berbeda nyata pada Uji Beda Nyata Terkecil (BNT) 5\%.

Hemiptera, araneida, Diptera, Odonata, Coleoptera, Hymenoptera dan Lepidoptera (Gambar 1.).

\section{Bobot berangkasan, Bobot 100 butir dan Kadar} Air Benih pada Tanaman Padi

Hasil penelitian menunjukkan bahwa semua perlakuan pada bobot 100 butir benih tidak berbeda nyata sehingga tidak mempengaruhi bobot berangkasannya. Pada pengamatan kadar air benih menunjukkan hasil berbeda nyata antar perlakuannya. Perlakuan compost tea + B. bassiana menunjukkan hasil tertinggi yaitu $9,73 \%$, sedangkan yang terendah yaitu perlakuan B. bassiana yaitu 9,23\%. Pada pengamatan bobot berangkasan antar perlakuan berbeda nyata. Hal tersebut dapat dilihat pada Tabel 5.

\section{Potensi Kesuburan Setelah Aplikasi B.bassiana} dalam Compost Tea pada Tanaman Mentimun

Penelitian ini untuk mengetahui tinggi tanaman, jumlah daun dan hasil dari pasca panen dari aplikasi compost tea dan B. bassiana pada tanaman mentimun (Tabel 6.).

\section{Pembahasan}

Data hasil pengamatan pada Tabel 1 tinggi tanaman padi menunjukkan bahwa perlakuan compost tea + B. bassiana berbeda nyata dengan kontrol dan perlakuan petani. Hal tersebut dikarenakan kandungan compost tea yang berbahan dasar jerami padi mampu meningkatkan kesuburan biologis tanah. Sejalan dengan penelitian Putri, (2015) bahwa jerami padi mengandung gabungan mikroba unggul, mampu mengefektifkan penggunaan pupuk anorganik khususnya dalam meningkatkan ketersediaan hara $\mathrm{N}$, P, K sehingga meningkatkan hasil panen.

Tabel 5.menunjukkan bahwa perlakuan compost tea + B. bassiana berbeda nyata terhadap bobot berangkasan padi dibandingkan dengan kontrol dan perlakuan petani. Hasil bobot berangkasan tertinggi yaitu sebesar 74,61 $\mathrm{g}$ dan hasil bobot terendah sebesar 59,61 g pada perlakuan kontrol. Hal tersebut karena pemberian Pupuk organik cair dapat menggantian pupuk urea secara umum. Unsur hara $\mathrm{N}$ yang terdapat pada Pupuk organik cair berperan penting pada fase pertumbuhan dan generatiftanaman. (Poerwowidodo, 1992, dalam Sastro, 2015).

Hasil penelitian menunjukkan tidak terdapat serangga hama maupun musuh alami yang terinfeksi $B$. bassiana, sehingga tidak mempengaruhi tingkat kematian serangga hama. Hal tersebut terjadi karena konsentasi jamur B. bassiana yang digunakan terlalu 
Tabel 5. Pengaruh Aplikasi Compost Tea yang Mengandung B. bassiana terhadap Bobot berangkasan, Bobot 100 butir dan Kadar Air Benih Tanaman Padi

\begin{tabular}{lccc}
\hline \multirow{2}{*}{ Perlakuan } & \multicolumn{3}{c}{ Pengamatan } \\
\cline { 2 - 4 } & Bobot 100 butir (g) & Bobot berangkasan (g) & Kadar Air Benih (\%) \\
\hline Kontrol & $2,49 \mathrm{a}$ & $59,61 \mathrm{~b}$ & $9,25 \mathrm{~b}$ \\
Perlakuan Petani & $2,49 \mathrm{a}$ & $65,15 \mathrm{~b}$ & $9,40 \mathrm{~b}$ \\
BB & $2,57 \mathrm{a}$ & $63,35 \mathrm{~b}$ & $9,23 \mathrm{~b}$ \\
Compost & $2,52 \mathrm{a}$ & $67,30 \mathrm{a}$ & $9,48 \mathrm{a}$ \\
Compost + BB & $2,57 \mathrm{a}$ & $74,61 \mathrm{a}$ & $9,73 \mathrm{a}$ \\
\hline
\end{tabular}

Keterangan : Angka-angka yang diikuti oleh huruf yang sama pada kolom yang sama menunjukkan tidak berbeda nyata pada Uji Beda Nyata Terkecil (BNT) 5\%.

Tabel 6. Tinggi tanaman, jumlah daun dan hasil dari pasca panen dari aplikasi compost tea dan B. bassiana pada tanaman timun.

\begin{tabular}{lllllllll}
\hline Perlakuan & Tinggi & $\begin{array}{c}\text { Jumlah } \\
\text { Daun }\end{array}$ & $\begin{array}{c}\text { Panjang } \\
\text { Akar } \\
(\mathrm{cm})\end{array}$ & $\begin{array}{c}\text { Berat } \\
\text { Basah } \\
\text { Akar } \\
(\mathrm{g})\end{array}$ & $\begin{array}{c}\text { Berat } \\
\text { Kering } \\
\text { Akar } \\
(\mathrm{g})\end{array}$ & $\begin{array}{c}\text { Berat } \\
\text { Basah } \\
\text { Batang } \\
(\mathrm{g})\end{array}$ & $\begin{array}{c}\text { Berat } \\
\text { Kering } \\
\text { Batang } \\
(\mathrm{g})\end{array}$ & $\begin{array}{c}\text { Kehijauan } \\
\text { Daun } \\
\text { (cci) }\end{array}$ \\
\hline $\mathrm{Ksr}$ & $63,06 \mathrm{~b}$ & $7,00 \mathrm{~b}$ & $27,50 \mathrm{a}$ & $3,45 \mathrm{~b}$ & $0,14 \mathrm{~b}$ & $10,39 \mathrm{~b}$ & $0,84 \mathrm{~b}$ & $5,01 \mathrm{~b}$ \\
$\mathrm{Ksm}$ & $84,70 \mathrm{~b}$ & $7,00 \mathrm{~b}$ & $28,16 \mathrm{a}$ & $4,80 \mathrm{ab}$ & $0,16 \mathrm{~b}$ & $12,44 \mathrm{~b}$ & $1,17 \mathrm{~b}$ & $4,56 \mathrm{~b}$ \\
$\mathrm{Kss}$ & $90,26 \mathrm{~b}$ & $7,40 \mathrm{~b}$ & $28,60 \mathrm{a}$ & $3,95 \mathrm{~b}$ & $0,12 \mathrm{~b}$ & $11,36 \mathrm{~b}$ & $0,94 \mathrm{~b}$ & $4,35 \mathrm{~b}$ \\
$\mathrm{Sr}$ & $100,18 \mathrm{~b}$ & $7,80 \mathrm{~b}$ & $29,00 \mathrm{a}$ & $5,31 \mathrm{ab}$ & $0,22 \mathrm{ab}$ & $17,75 \mathrm{a}$ & $1,47 \mathrm{ab}$ & $4,94 \mathrm{~b}$ \\
$\mathrm{Sm}$ & $100,66 \mathrm{~b}$ & $9,40 \mathrm{ab}$ & $29,17 \mathrm{a}$ & $4,48 \mathrm{~b}$ & $0,17 \mathrm{ab}$ & $17,60 \mathrm{a}$ & $1,49 \mathrm{ab}$ & $5,25 \mathrm{~b}$ \\
$\mathrm{Ss}$ & $99,80 \mathrm{~b}$ & $7,80 \mathrm{~b}$ & $28,78 \mathrm{a}$ & $5,31 \mathrm{ab}$ & $0,19 \mathrm{ab}$ & $16,53 \mathrm{a}$ & $1,26 \mathrm{ab}$ & $5,63 \mathrm{ab}$ \\
$\mathrm{sr} \mathrm{bb}$ & $121,44 \mathrm{a}$ & $9,20 \mathrm{ab}$ & $28,30 \mathrm{a}$ & $6,23 \mathrm{a}$ & $0,23 \mathrm{a}$ & $19,41 \mathrm{a}$ & $1,80 \mathrm{a}$ & $5,91 \mathrm{ab}$ \\
$\mathrm{sm} \mathrm{bb}$ & $126,64 \mathrm{a}$ & $10,60 \mathrm{a}$ & $28,44 \mathrm{a}$ & $5,05 \mathrm{ab}$ & $0,18 \mathrm{ab}$ & $20,28 \mathrm{a}$ & $1,72 \mathrm{a}$ & $6,39 \mathrm{ab}$ \\
$\mathrm{ss} \mathrm{bb}$ & $103,88 \mathrm{~b}$ & $8,80 \mathrm{~b}$ & $29,38 \mathrm{a}$ & $5,41 \mathrm{ab}$ & $0,16 \mathrm{~b}$ & $18,63 \mathrm{a}$ & $1,59 \mathrm{ab}$ & $5,63 \mathrm{ab}$ \\
\hline
\end{tabular}

Keterangan : Angka-angka yang diikuti oleh huruf yang sama pada kolom yang sama menunjukkan tidakberbeda nyata pada Uji Beda Nyata Terkecil (BNT) 5\%. (Ksr : kontrol siram, Ksm : kontrol semprot, Kss : kontrol siram semprot, Sr : siram compost tea, $\mathrm{Sm}:$ semprot compost tea, $\mathrm{Ss}:$ siram semprot compost tea, srbb : siram compost tea $+B$. bassiana, smbb : semprot compost tea + B. bassiana, ssbb : siram semprot compost tea + B. bassiana .

rendah yaitu hanya $100 \mathrm{~g} / 81$ atau $1,25 \mathrm{~g} / 100 \mathrm{ml}$. Attami (2013), menyatakan bahwa konsentrasi $10 \mathrm{~g} / 100 \mathrm{ml} B$. bassiana dapat menyebabkan tingkat mortalitas wereng batang coklat sebesar 74,44 tetapi pada hama tidak tumbuh B. bassiana. Namun Beauvaria bassiana dapat menekan hama-hama yang terdapat pada tanaman padi seperti yang dapat dilihat pada Tabel 4. yaitu jumlah arthropoda pada perlakuan Beauvaria bassiana sebanyak 70,75 ekor.

Penelitian ini dilakukan di lapangan terbuka yaitu di lahan sawah seluas $1600 \mathrm{~m}^{2}$ tanpa ada sungkup untuk tanaman padi tersebut, tidak dilakukan introduksi serangga pada lahan tersebut sehingga serangga hama maupun musuh alami dapat dengan bebas tumbuh dan berkembang biak pada lahan penelitian ini. Karena lahan penelitian berada pada lingkungan terbuka maka iklim mikro pada lahan tersebut tidak dapat dikontrol. Hal tersebut memungkinkan terganggunya proses infeksi B. bassiana terhadap serangga. Menurut (McCoy et al., 1988 dalam Soetopo et al., 2007) seperti 
cendawan lain, pertumbuhan B.bassiana juga sangat ditentukan oleh kelembaban lingkungan. Temperatur optimum untuk perkembangan, patogenisitas,dan kelulusan hidup cendawan umumnya antara $20-30^{\circ} \mathrm{C}$. Hal ini mebuktikan bahwa seluruh perlakuan tidak memberika pengaruh terhadap pertumbuhan dan perkembangan arthropoda sehingga arthropoda dalam lahan penelitian masih mampu tumbuh dan berkembang dengan baik.

Pada penelitian ini arthropoda yang paling banyak ditemukan adalah ordo Diptera family Drosophilidae, ordo Diptera family Phoridae dan ordo Diptera familyAsilidae. Sebagian besar jenis serangga bukan merupakan serangga hama yang merugikan tetapi merupakan musuh alami hama (predator, parasitoid), dan serangga penghancur sisa-sisa bahan organik yang sangat bermanfaat. Arthropoda ordo Diptera family Drosophilidaea dalah lalat-lalat buah kecil, lalat ini bersifat ektoparasitik (pada ulat-ulat) atau bersifat pemangsa (pada mealybugs dan Homoptera kecil lainnya) pada tahap larva (Borror, 1992). Ordo Diptera family Phoridae adalah lalat bongkok yang kecil sampai sangat lembut yang bersifat parasit.Ordo Diptera family Asilidae adalah lalat perampok atau lalat rumput. Lalat ini bersifat pemangsa dan menyerang berbagai ragam serangga, yang mencakup tabuhan, lebah, capung, belalang dan lalat-lalat lainnya.Mereka dapat menyerang serangga yang lebih besar dari ukurannya. Kebanyakan Asilidae menangkap korban mereka pada waktu terbang tetapi lalat-lalat rumput (Leptogastrinae) biasanya menyerang serangga - serangga yang sedanghinggap atau beristirahat (Borror, 1992).
Pada Tabel 6. terlihat bahwa perlakuan berpengaruh nyata terhadap semua variabel pengamatan kecuali pada variabel pengamatan panjang akar. Variabel pengamatan tinggi tanaman padi, jumlah daun, berat basah akar, berat kering akar, berat basah batang, dan kehijauan daun yang paling tinggi yakni pada perlakuan compost tea plus B. bassiana (Sm bb). Sedangkan paling rendah yakni pada perlakuan kontrol siram (Ksr) pada pengamatan Tinggi tanaman, jumlah daun, berat basah akar, berat basah batang, dan berat kering akar. Pada pengamatan panjang akar seluruh perlakuan memiliki nilai yang hampir sama sehingga dapat terlihat bahwa seluruh perlakuan tidak mempengaruhi panjang akar padi. Tabel 6 menunjukkan pula bahwa perlakuan kontrol baik pada kontrol siram, kontrol semprot dan kontrol semprot siram menghasilkan nilai pengamatan terendah dibandingkan dengan perlakuan lainnya. Hal tersebut memperlihatkan bahwa penyiraman compost tea beserta $B$. bassiana dan penyemprotan compost tea beserta $B$. bassiana dapat mempengaruhi tinggi tanaman secara signifikan karena compost tea terbukti dapat memperbaiki kesuburan tanah secara langsung, meningkatkan jumlah mikroba tanah dan akivitasnya dalam menetralisir bahan organik tanah, melarutkan unsur hara yang terjerap serta mengikat ion (Arancon, 2007). Selain itu pengaruh B. bassiana yang ditambahkan pada compost tea dapat mengendalikan hama di sekitar tanaman timun sehingga pertumbuhan tanaman timun tidak terganggu. Hal ini dipertegas dari hasil penelitian (Daud, 1993 dalam Soetopo et.al., 2007) yang menyatakan bahwa $B$. bassiana berpotensi mengendalikan ulat pemakan daun kelapa Darna 
catenata yang sering menyerang tanaman kelapa sawit di Sulawesi hingga merusak titik tumbuh.

\section{KESIMPULAN}

Berdasarkan hasil penelitian dan pembahasan yang telah diuraikan, maka dapat disimpulkan bahwa perlakuan compost tea + B. bassiana tidak nyata mempengaruhi peningkatan pada variabel jumlah anakan, kehijauan daun, jumlah arthopoda, bobot 100 butir benih dan kadar air benih, tetapi nyata mempengaruhi variabel pengamatan tinggi tanaman dan bobot berangkasan. Selain itu penambahan B. bassiana pada compost tea tidak menyebabkan terjadinya infeksi pada serangga hama yang terdapat pada pertanaman padi, karena dosis yang masih terlalu rendah.

\section{UCAPAN TERIMA KASIH}

Ucapan terima kasih disampaikan kepada Kementerian Riset, Teknologi, dan Pendidikan Tinggi yang telah membiayai kegiatan penelitian ini melalui Hibah Bersaing (Penelitian Produk Terapan) tahun anggaran 2016.

\section{DAFTAR PUSTAKA}

Agus, F., A. Adimihardja., S. Hardjowigeno., A.M. Fagi., \& W. Hartatik. 2004. Tanah

Sawah danTeknologi Pengelolaannya.http:// balittanah.litbang. pertanian.go.id/ind/ index.php/publikasi-mainmenu-78/bukumainmenu-85/843-tanah-sawah. Diakses 10 september 2018 .

Arancon N.Q., C.A. Edwards., R. Dick., \& L. Dick. 2007. Vermicompost Tea Production and Plant
Growth Impacts.BioCycle. 48(11):51-52.

Attami, I.M. 2013. Efektifitas Pemberian Jamur Beauveria Bassiana dalam Mengendalikan Wereng Coklat (Nilaparvata Lugens) dan Pengaruhnya Terhadap Pertumbuhan Serta Hasil Tanaman Padi Basmati. Pp47-53.

Badan Pusat Statistik. 2017. Luas Lahan, Produktivitas, Produksi, dan Pertumbuhan Produksi Padi Nasional Tahun2000-2017. Badan Pusat Statistik. Jakarta. www.bps. go.id. Diakses 17 september 2018.

Badan Pusat Statistik. 2018. Produksi Padi Menurut Provinsi (ton), 1993-2015. http://www.bps. go.id/linkTableDinamis/view/id/865. Diakses 8 februari 2019.

Baehaki, SE. 2013. Hama Penggerek Batang Padi dan Teknologi Pengendalian. IPTEK Tanaman Pangan. 8 (1):1-14.

Borror, J.D., T.A. Charles., \& J.F. Norman. 1989. An Introduction to the Study of Insects. Diterjemahkan Partosoedjono, Soetiyono dan Brotowidjoyo, D. Mukayat. Indonesia edition :Pengenalan Pelajaran Serangga, Edisi keenam. 1992. Gajah Mada Universitas Press. Universitas Gajah Mada. Yogyakarta. $1083 \mathrm{hlm}$.

Herlinda, S., S.I. Mulyati., \& Suwandi. 2008. Jamur Entomopatogen Berformulasi Cair sebagai Bioinsektisida untuk Pengendali Wereng Coklat. Jurnal Agritrop. 27(3):119-126.

Hmouni, A., A. Mouria., \& D. Allal. 2006. Biological control of tomato grey mould with compost water extracts, Trichoderma sp., and Gliocladium sp.Phytopathol. Mediterr. 45:110-116. 